\title{
Columbia University Seminars on the History of the Working Class
}

\section{Judith Wishnia}

State University of New York at Stony Brook

State policy, working class political behavior and work discipline were the dominant themes of the Columbia University Seminars on the History of the Working Class for the fall of 1981. Two papers, given by Herman Lebovics and Judith Wishnia, both of the State University of New York at Stony Brook, treated the response of the governments of Third Republic France to growing working class militancy. Lebovics' paper, Protection Against Labor Troubles: The Case of the Méline Tariff, postulated that the passage of the high protective tariffs of the 1880 s and 1890 s were not, as has been previously analyzed, simply an effort to cement the alliance between industrialists and agriculturalists, but rather calculated state policy to appease worker demands for higher wages. Faced with violent strikes, largely in the textile industry, at the end of the Second Empire (late 1860s) and once again in the depression period of the $1880 \mathrm{~s}$, French industrialists attempted to formulate a policy which would raise wages without lowering profits. Using as evidence, the speeches and statements of pro-tariff industrial organizations and their main government spokesman, Jules Méline, Lebovics indicated that large numbers of industrialists turned to the protective tariff as one way to achieve this goal. He concluded that it is difficult to determine the success of the policy-real wages rose in the first years of the new century, but worker militancy, after some years of quiescence in the wake of the tariffs, erupted again. But it seems clear that succesful or not, the intent of the tariffs was to alleviate worker discontent.

Wishnia's paper, "The Development of Class Consciousness and Unionization of French Fonctionnaires" (civil service workers), traced the growth of state employment and the gradual development of fonctionnaire militancy. Forbidden by law to unionize and to strike, French fonctionnaires nevertheless organized, utilizing both the organizational form (the syndicat) and the tactics (the strike) of the blue-collar working class. As the fonctionnaires moved closer to unionism, the major blue-collar federation, the CGT, was abandoning much of the revolutionary rhetoric and ideology which had helped to keep the two groups of workers apart, and after World War I, the fonctionnaires entered the CGT. 
Wishnia sees fonctionnaire consciousness growing out of changing social origins, and eroding standard of living, routinization and expansion of work, and bluecollar organization and militancy, but she postulates that most critical was the role played by the state itself. The very centralization of state employment and the state's authoritarian response to fonctionnaire demands were crucial factors in making fonctionnaires identify themselves as part of the working class.

Turning to American history and politics, and specifically the influence of the working class on the two party system, Anthony Gronowitz of John Jay College, City University, concentrated on the Working Class and the Democratic Party in New York City. Using data on the ethnicity, occupation, and placement in the party hierarchy of 5,000 Democratic activists in the years 1844 and 1884, Gronowitz showed that, whereas significant numbers of skilled workers participated in Democratic Party politics in 1844, their numbers decreased significantly by 1884 , indicating a shift of influence and support from the Democratic Party to various third parties. Gronowitz also indicated that unlike Europe, where working class consciousness was more developed and political influence more important, questions of race and ethnicity, utilized for victory by the Democrats in New York in 1844, fractured the New York working class and weakened its influence on the major parties after the Civil War.

Changing the medium and the subject matter, Eric Breitbart showed his film, Clockwork. A depiction of the development of scientific management and automation, specifically the work of Frederick Winslow Taylor, the film contrasts the workshop atmosphere of nineteenth century factories where workers were often involved in planning and production decisions, with factories where management, through the use of Taylorism, has taken over all control of the workplace. Films and photographs made by Taylor show how muscle and limb movements were charted, timed and analyzed, so that work could be split into simple tasks and regulated by the clock, permitting the total separation of thinking, now in the hands of management, from the labor of the worker. The film is available from California Newsreel, 630 Natoma Street, San Francisco, California 94103.

Finally the subject returned to French politics when the seminar met in a special session to hear Patrick Fridenson of the University of Paris at Nanterre. The author of a study of Renault automobile workers and a leader of the higher education section of one of the major unions of France, Fridenson discussed the nationalization of numerous banks, public utilities and several key industrial plants in the aftermath of World War II. These nationalizations were important precedents for the expanded nationalization planned by the current Socialist government.

The Seminar continues to look for interesting papers. Anyone interested in giving a paper in 1982/83, contact Helmut Gruber, 425 Riverside Drive, New York, New York 10025. 